\title{
I. On two new species of Narcissus
}

E.E.

To cite this article: E.E. (1824) I. On two new species of Narcissus, Philosophical Magazine Series 1, 63:309, 7-7, DOI: 10.1080/14786442408644454

To link to this article: http://dx.doi.org/10.1080/14786442408644454

曲 Published online: 29 Jul 2009.

Submit your article to this journal 준

III Article views: 3

Q View related articles $₫$ 


\title{
PHILOSOPHICAL MAGAZINE AND JOURNAL.
}

\author{
$31^{\text {st } J A N U A R Y 1824 .}$
}

I. On two new Species of Narcissus.

To the Editors of the Philosophical Magazine and Journal.

Gentlemen,

W

HEN you published in yourlast Number, p. 440, Mr. Haworth's excellent account of a nerw Genus of Narcissea, you were not aware that the two species there noticed had been described, and one of them actually figured, in The Botanical Register, as new species of Narcissus, with specific names under which they have been known and distinguished for the last two years, and which I am persuaded Mr. Haworth has no desire to change. The Diomedes minor of $\mathrm{Mr}$. Haworth is Narcissus Macleayi of the Botanical Register. This plant appears to have been long lost to our gardens until recently imported by the Secretary to the Linnæan Society, among other bulbs, from Smyrna. Mr. Haworth's D. major is figured in the Botanical Register, and named Narcissus Sabini, in honour of the worthy Secretary of the Horticultural Society, whose thorough knowledge of the genus fully entitles him to this distinction, independently of the circumstance of his having recently restored this species to the notice of British botanists. Whether the beautiful genus of Narcissus ought to be divided into many genera, must be left to botanists to decide; but I suspect that Diomedes will not be considered a good name for a genus of plants, as being not sufficiently distinct from the genus Diomedea of Linnæus.

Yours \&c.

E. E.

Vol. 63. No. 309. Jan. 1824.

A 2

II. $O n$ 